\title{
THE RIGHT TO A RAINBOW CITY: THE ITALIAN HOMOSEXUAL SOCIAL MOVEMENTS
}

\author{
FABIO CORBISIERO $^{1} \&$ SALVATORE MONACO ${ }^{2}$ \\ ${ }^{1}$ University of Naples Federico II, Department of Social Sciences, Vico Monte della Pietà 1, 80138, \\ Naples, Italy. ORCID: 0000-0001-7947-2497, Email: fabio.corbisiero@unina.it \\ ${ }^{2}$ Free University of Bozen, Faculty of Education, Regensburger Allee 16, 39042, Brixen, Italy. ORCID: \\ 0000-0002-4218-6267, Email: salvatore.monaco@unibz.it
}

ABSTRACT: Nowadays, the legal status of homosexual people varies widely from one country to another (ILGA 2019). In many contexts, the homosexual social movement has played a central role in fighting heterosexism and homophobia (Weinberg 1983). Especially in the democratic world, the homosexual social movement has been capable of spreading solidarity and inclusion and also of leading changes in regulatory terms, with different results context by context (Adam, Duyvendak, Krouwel 1999). The paper aims to point out the Italian situation and the main characteristics of the gay social movement in Italy as key factors of the social change. More specifically, the paper is aimed at recounting the political process and the symbolic and cultural factors that led the Italian homosexual social movement to impose itself on the social scene as a reality with its own specific identity. The paper's last section analyses the so-called "Italian rainbow cities", urban contexts where the LGBT community is highly concentrated and in which it is so active as to stimulate, in cooperation with the local urban administrations, capacity-building processes oriented to the construction and consolidation of LGBT people's rights and social inclusion.

KEYWORDS: Italy, homosexual movement, rainbow cities, Mayors, LGBT 


\section{INTRODUCTION}

Homosexuality is an emotional interest and/or sexual orientation or behavior between people of the same sex or gender (Harrold 1999; Grueter \& Stoinski 2016). The propagation of homosexuality in humans is difficult to determine accurately, although in many ancient cultures homosexual relationships were highly prevalent (Hekma 2006). Throughout history, some aspects of homosexuality have been admired or condemned, according to the various specific societies' sexual norms. In some of these, same-sex behaviours and attitudes have been generally accepted, even honoured (Hutte 1978). In other times and places they have been considered reprobate and illegal, prohibited and punished by law (Levine 1979).

Since the mid-twentieth century, homosexuality has gradually been disregarded as a crime or disease and decriminalized in nearly all progressive nations (Bernstein 2005). However, nowadays the legal status of homosexual relations varies widely from one country to another but jurisdictions which consider certain homosexual behaviors as crimes and punish them with severe penalties, including death, still remain (ILGA 2019) ${ }^{1}$.

Urban contexts have played a central role in fighting heterosexism and homophobic pressures of a still very heteronormative society, with different results context by context (Weinberg 1983; Adam, Duyvendak, and Krouwel 1999). Sexual identities sociologists have conceptualised cities, as Kath Weston notes, as an "escape from the isolation of the countryside and the surveillance of small-town life in contrast to the freedom and anonymity of the urban landscape" (1998: 274). These scholars have started to problematise the "gay imaginary" in which gay men and lesbian women conceive urban areas as synonymous of homosexual spaces and, consequently, leave rural areas in favour of urban areas. This imaginary was initially described by Weston as gay men and lesbian women of the 1970s started to flock from towns to the larger cities of the U.S. in search of a place to live out their homosexual identity.

More specifically, urban sociology spent time to recognise that sexuality is as foundational to the making of social and spatial orders as the categories of gender, class, or race. Initial insights into the place of sexuality in the city were hence restricted to consideration of the distributions of "zones of vice" and studies of "deviant phenomena” (Reckless 1962; Symanski 1974). However, those physical boundaries that urban sociology would define as "deviant spaces", became epicenters of an international countercultural identity movement that gave definition to the "gay self" and challenged broader heterosexual assumptions surrounding sex, gender, sexual orientation, and sexual identity (Lauria and Knopp 1985; Epstein 1987).

The increased visibility of lesbian and gay life in a range of Western cities in the

\footnotetext{
${ }^{1}$ Homosexuality is illegal and punishable by prison sentences and fines in 72 countries. The crime of sodomy is condemned with the death penalty in 5 Islamic nations (Saudi Arabia, Iran, Mauritania, Sudan and Yemen). The lack of tolerance towards the homosexual community is not a prerogative only of Asia and Africa. In America, in fact, there are (still) 11 countries that criminalize homosexuality, 9 in Oceania, and in Europe, the Turkish Republic of Northern Cyprus provides for up to five years in prison for the crime of sodomy.
} 
1970s and 1980s (San Francisco, New York, Amsterdam or London) saw pioneering studies emerge, highlighting the importance of gay neighborhoods ("gay ghettos" or "lavender ghettos") in the social, economic and political life of those whose lives fell outside the heterosexual "standards" (Weinberg and Williams 1974; Castells and Murphy 1982). For example, Humphreys (1972) has labeled as "gay ghettos" the neighborhoods connoted by marked tolerance of homosexuality and a clustering of gay residences and facilities. These urban areas are distinguished in their cities by the social practices of their users and inhabitants, the specificities of their economic activity, or their contribute to creativity or social integration. These territories have been characterized not only by the coexistence of diverse lifestyles, trajectories and identities, but were also used to conceptualize gay people as a legitimate minority group, having a certain "quasi-ethnic" status, and deserving the same protections against discrimination that are claimed by other groups in society. The "politics of identity" have settled nearby a notion of "gayness" as a not arbitrary social difference. Sociologist Manuel Castells' (1983) essential study on San Francisco documented many of these factors in rich ethnographic detail. He hypothesised that homosexual people moved into urban spaces because cultural change allowed for sexual "experimentation". Other scholars have since hooked upon Castells' analysis, describing further social dimensions related to mass urban migration into cities (Jackson 1989; Armstrong 2002; Brown and Knopp 2003). In contrast to the Castells ethnography, which states that the visibility of homosexual people and the spatial consequences are primordial in the process of resistance, Knopp and Brown, for instance, state that daily survival strategies can be every bit as meaningful and important in people's lives as revolutionary social change. They specifically look at the way in which queer subjectivities are constructed in small and non-metropolitan areas. The evidence from these researchers strongly suggests that upward, sideward, and multi-scalar flows of people and ideas may be just as important in the shaping of cultures and politics both in large and small metropolitan or non-metropolitan areas as simple downward flows. During recent decades, there has been a growing concern about the decline of "gay neighborhoods" analysis. This is in part due to a greater mainstream acceptance of certain gay and lesbian identities and lifestyles: on one hand, gay neighborhoods are no longer considered as a significant part of identity formation, self-affirmation and mutual support among sexual minorities (Gorman-Murray and Waitt 2009; Monaco 2019), on the other, decline of gay ghettos is an outcome of the domination of tourism and urban marketing strategies over these spaces (Alderson 2016; Corbisiero 2016). By the mid-1990s, as neoliberal policies drove an entrepreneurial and competitive urban regime, the need to market and promote the city as a "gay-friendly" place and an attractive destination to live in became paramount (Harvey 1989; Boudreau, Keil and Young 2009). For some scholars (Floyd 2009) living in urban contexts has prevented the impact of the neoliberal lifestyle and has produced 'homonormativity' effects. Further salient factors characterised gay and lesbian migration into cities. Bailey (1998) has noted that gay and lesbian people were driven into the city by the desire for local political power and a general sense of safety and anonymity.

Recent urban studies have become arguably more important in the last twenty 
years by considering the broader ways that urbanization shapes sexual practices, new homosexual identities and spaces of resilience (Browne, Lim \& Brown 2007; Doan 2010; Hubbard 2011).

A part of these studies have taken up the project of analysing gay and lesbian lives beyond metropolitan centres by focusing on rural areas (Gorman-Murray, Pini and Bryant 2012; Gorman-Murray, Waitt and Gibson 2012) and, more recently, on smaller or "ordinary" cities (Browne 2007; Muller Myrdahl 2013). By contrast, the safety of gay ghettos within cities has been brought into question (Myslik 1996) and rural areas have also been advanced as sites of sexual liberation (Kramer 1995). In tandem, metronormativity has become a central queer critique of lesbian and gay studies, exemplified by works such as Herring's (2010) examination of the history of American queer anti-urban movements or Tongson's (2011) relocations of queer life to the landscapes of new suburbia, both of which demonstrate the limitations involved in constructing the urban as the authentic space of all gay liberation movements.

The focus of the paper is to point out the Italian situation and the main characteristics of the homosexual movement in Italy as key factors for the social change. More specifically, the paper is devoted to describing in detail the history of the Italian homosexual social movement and some of the most interesting effects that have been achieved at local and national level from a normative and social perspective. Thus, the aim of this paper is to analyse the "Italian rainbow cities" patterns which configure a not homogeneous geography for gay and lesbians rights as a result of political and normative weakness. This focus puts emphasis on geography and socio-political patterns instead of sexuality. In doing so, it also downplays the connection between sexuality and urbanity, thereby contributing both to the growing literature within sociologies of sexualities and urban LGBT studies.

The first section is aimed at recounting the political process and the symbolic and cultural factors that led the Italian homosexual social movement to impose itself on the social scene as a reality with its own specific identity, although some of its inner niches are sometimes in conflict with each other. Despite some internal differences, the glorification and celebration of Gay Pride, and the frequent use of symbols (such as the rainbow flag) and non-verbal language, have given visibility to the requests of the Italian homosexual community, legitimizing its identity.

The second section of the paper is dedicated to the long Italian public discussion and to the various parliamentary proposals that have been made in Italy in the wake of the social movement and that only in recent years have resulted in some significant changes.

The paper's last section analyses the so-called "Italian rainbow cities" (Corbisiero 2013; Corbisiero \& Monaco 2017). These are urban contexts where the LGBT community is highly concentrated and in which it is so active as to stimulate, in cooperation with the local urban administrations, capacity-building processes oriented to the construction and consolidation of LGBT people's rights and social inclusion.

The rainbow cities appear to be founded on a milieu of economic, political, cultural, social and urban dimensions whose main objective is to ensure a full citizenship to LGBT people. Quoting Marshall (1976) the right of citizenship is a status given to 
those who are full members of a community; all the people who possess this status are equal with respect to rights and duties.

\section{THE ITALIAN HOMOSEXUAL MOVEMENT: URBAN HIERARCHIES?}

The Henri Lefebvre framework about the "right to the city" (1968) offers a series of perspectives regarding the political potential of the urban experience and helps us to understand how space as a social and historical set of processes is understood, constructed, lived, and perceived (Lavinas Picq and Thiel 2015).

Lefebvre's concern with the alienating impact of the modern city emphasised an increasing disconnection between urban inhabitants and their abilities to participate in the production of spaces that highlight the processual nature of capitalist social space (Harvey 2000).

While the citizens' involvement in the right of the city has gradually come to be seen as one of the crucial factors of democratic urban development (Purcell 2003), it remains unclear which of many LGBT initiatives should be included in the use of spaces (including services and infrastructure) and how to compromise between their often conflicting goals.

Many urban initiatives emerge in order to protect a certain space or place, like in the case of heritage protection groups, but also cultural or social centers, squats and so on.

The 1969 Stonewall Riots, for instance, mark the beginning of the modern "LGBT right to the city" and show that transformative events can have multiple enduring effects on the history of an urban movement. The riots certainly served as a catalyst for widespread mobilization (D'Emilio 1983). When they turned their attention to the cause of "gay liberation" they brought the tactical repertoires and collective action frames they had acquired in those other urban movements with them. These included adopting the concepts of "coming out" and "Gay Pride" as a way of creating visibility, disrupting heteronormative cultural codes, and generating a new socio-political identity, and the creation of "safe" spaces for political-consciousness raising. In Italy the scholars pay attention to the various political strategies and values that the movements adopt and the State-city-community relationships. Although a ranking of metropolitan areas by their all above gay and lesbian concentration finds low statical values even in Italy's most attractive cities as Naples, Rome or Milan, Italy was crossed by a wide network of associations which played an important role in shaping LGBT urban social movements and political activism (Curati 2013). Over time the level of diversity and complexity of this network increased, and its composition was dynamically changing with the transition of some organizations from the area of civil society to the field of public services or party politics and the emergence of new allies. The analysis of the multitude of speeches, projects, experiences and militant practices lived by the Italian LGBT movement suggests more than a path of slow and progressive evolution of the construction of a collective identity. Italian LGBT movement has lived a discontinuous overlapping of "political moments" (Prearo 2015: 17) that emphasise the breaks and the discontinuities between national, local politics and movement. The 
Italian LGBT reality is still characterized by a multitude of political divisions and by a huge variety of collective actions that take place exclusively in urban contexts.

The US Stonewall riots caused, also in Italy, the birth of revolutionary groups, social movements, and sexual liberation collectives in various cities of the country, especially the largest ones, such as Rome, Turin and Bologna. While recognising the importance of these and other socio-cultural factors, the Italian political-structural environment in which LGBT organizations have historically existed has had a profound effect on the nature of organizations as well as their changing ability to influence Italian political outcomes. To use the language of social movement theorists, the political opportunity structure in Italy has not always been particularly favourable to LGBT movement organizations. In the spring of 1971 the association F.U.O.R.I (Fronte Unitario Omosessuale Rivoluzionario Italiano) was founded and through its own magazine "Fuori" started a critical debate on the homosexual condition in Italy (Rossi Barilli 1999).

Italian homosexual social movement's issues were considered interesting by the "Radical Party", who shared its same liberal and non-violent revolutionary attitude. Nevertheless, a negative policy legacy, the somewhat closed nature of the Italian political system and the lack of culture about civil and human rights came together to create comparatively adverse opportunity structures for LGBT organizations.

During the eighties, the Italian homosexual social movement reorganised its activities through the creation of "Arcigay", a cultural and recreational homosexual association of the Italian Communist Party (Pezzana 1996). ${ }^{2}$

At that specific historical time, in the wake of the feminist movements that had started in the previous decade, the Italian lesbians gradually abandoned the gay collectives, because they no longer felt fully represented by the logic and dynamics of male homosexuals. This process has enabled a cleavage mechanism within the homosexual social movement which quickly led to the establishment of associations made up of lesbian women only or trans* women only.

In 1982 in Bologna the first group of homosexual urban culture (its first name was "Collectivo frocialista"; it later became "Circle 28 June”) was officially recognised by the City Council of Bologna. This event represents an important moment in the history of the Italian LGBT movement, because the institutional recognition of the homosexual movement by a local government legitimated its right to enjoy an institutional endorsement.

The new millennium brought additional progress toward the homosexual Italian movement's main goals of curbing homophobia as well as the ruling heterosexism. The main focus of the homosexual social movement's claims became the legal recognition of civil rights, above all same-sex unions, also requested by a strategy of continuous pressure on national policies in collaboration with other institutions such as media, political parties and universities. And not least a further goal was strengthening anti-discrimination laws.

\footnotetext{
${ }^{2}$ The first Arcigay association was born in Palermo, after the civic mobilization caused by the homophobic murder of two young gays. That crime generated a fast spreading of territorial gay, lesbians and trans movements and organizations.
} 
In some urban areas, the Italian homosexual social movement achieved interesting results: in Rome, for example, the administration delegated the management of home services dedicated to HIV-positive people and AIDS patients to the LGBT associations. A decade later, Rome became the Gay capital, hosting the World Pride in the Jubilee year 2000 (Sanna \& Bersacchi 2000; Barbagli \& Colombo 2001). In this sense, the cities started a phase of reaching political participation aimed at a constant claim of civil rights (D'Albergo \& Moini 2007). This kind of inclination has attracted more and more homosexual people to metropolitan areas.

The homosexual social movement generated a proliferation of associations and informal groups. This phenomenon on one hand has been a strong point for the whole LGBT community, which has established itself on the Italian social scene through a plurality of voices, expressions of diversified needs. On the other hand, the power disparity among the various associations and the involved actors generated some internal conflicts, often making the dialogue difficult among them, especially with the more subversive components such as queer and transgender people. These frictions were created around the power of "Arcigay" and its network abilities. In the process of restructuring the civil rights, "Arcigay” consultancy became increasingly formalised, giving rise to partnerships in which the local administration capitalised on the resources present in its area, recognising, in fact, the role of this organization as a broker between the social needs and the territories.

This division between institutionalization tendencies, carried out by "Arcigay”, and movementist policies has been continually re-discussed and the birth, in the last ten years, of other associations such as "Famiglie Arcobaleno" (association of families with LGBT parents) and "Anddos" (association of gay clubs) exacerbated the conflict questioning the ability of militant communities to mobilise and produce social changes.

\section{THE ITALIAN LGBT CIVIL RIGHTS AND THE POLITICAL AGENDA}

LGBT human and civil rights advocacy is often described in monolithic terms. In politics and popular media, references to a "gay agenda" or a "gay rights movement" are ubiquitous. In early 2000's the increasing focus on human and civil rights led the Italian homosexual movements - not without difficulties - to insert the question of the equality of homosexual people's rights to the center of the political agenda. Thanks to a relentless and constant action of pressure by the homosexual movement and other actors of the Italian civil society, in recent decades "the homosexual issue" has attracted the attention of the Parliament and has fully entered the public debate. The discussion of Italian politics on the issue of LGBT rights and claims represents a break with a past of intolerance and exclusion.

Empirically, however, public policies in favor of homosexual people have been few and limited. During over twenty years, the Italian Parliament has never been able to pass a single law in favor of homosexual equality. Historically, Italian politics has faced for the first time the issues related to the rights of homosexual people only between 1988 and 1996, when a weak debate started about the legalization of same- 
sex unions (without marriage) through a proposal of law for each of the legislatures of that period. Proposals would continue to come one after another until 2016, when Renzi's government passed the law "Regulation and discipline of civil unions between same-sex people”.

Despite this partial result, not only is it still not possible in Italy for same-sex partners to marry, but homoparental families are not yet legally recognised. Two samesex partners can register their civil partnership, but even if the couple is legally recognised, this does not apply to parental rights: the "non-biological parent" or "social parent" cannot recognise their partner's child as their own.

So, at present, Italian law does not protect the children living in these families, leaving it to the judges to grant a special adoption, when this is considered in the interest of the child, to registered couples who request it. ${ }^{3}$ The judge's discretional decision to secure a relational-affective relationship with the non-biological children (with consequent waste of time and money) increases even more the distance with the "traditional" families (Gargiulo 2008; Romeo 2011). Thus, the current civil union law creates a sharp division between families with heterosexual parents and the rainbow ones, with the risk that the homoparental families can be labeled as "dysfunctional", because they do not follow the (hetero)sexual standards (Rinaldi 2012).

Unlike other Countries, a law that condemns discrimination based on homophobia and transphobia is also missing in Italy. So, this kind of behaviours is not considered as a criminal offense.

In summary, from a legal point of view, Italy still seems far from granting homosexual people a full citizenship. The regulatory deficiency has a number of consequences connected with one another. First of all, the institutional homonegativity generates phenomena of minority stress in homosexual people (Meyer 2003). As it is known in the literature, hostile and stigmatising contexts put individuals who belong to a discriminated minority in a continuous stress condition (Herek 2004). Secondly, the Italian legal deficit implies a necessary intervention by the courts, called to respond to instances of recognition of homosexual people's rights in an anti-discrimination function. Last but not least, these deficiencies have the effect to give more strength to the homosexual movement and, more in general, to the whole LGBT community (Pichierri 2014; Pini 2011).

The renewed title $\mathrm{V}$ of the Italian Constitution, that through the subsidiarity principle gives local authorities the opportunity to re-build and re-orient the legal system, has moved the homosexual social movement's claims to the local political level, too.

So, mainly in larger cities, thanks to the collaboration of some gender-sensitive Mayors, there is an institutional civic culture oriented toward integration and social inclusion through local welfare policies and cultural actions (Monaco, Urciuoli \& Zaccaria 2015).

\footnotetext{
${ }^{3}$ Article 44 paragraph 1 of Law no. 184 of 1983 and subsequent amendment.
} 


\section{THE BUMPY ROAD FOR LGBT RIGHTS IN ITALY: THE ROLE OF RAINBOW CITIES}

During the nineties of the last century homosexual social movements, in response to an inconclusive action by the national government, began to pressure local governments in various Italian cities demanding more social justice, at least locally. Within the framework defined by law, the local authorities have regulated the citizens' lives in view of the concrete (or sometimes symbolic) implementation on their own territory of a system of practices and inclusion services aimed at the homosexual population.

As a consequence, since that time, an unprecedented alliance between social movement and political apparatus has also given birth to collectives such as Cods (Homosexual Coordination of Democrats) or Gayleft of the Democratic Party. In this scenario, the less proactive national policy has agreed to delegate territorial policies to intervene. Local administrations proved to be less ideological and more pragmatic. The reasons why the homosexual Italian movement has chosen to address local administrations to face the regulatory gap are various: local politicians are more accessible, closer to local associations, they have good communication skills and a good degree of collaboration with the media system.

The engagement with the local administrations has been a good strategy that the Italian homosexual urban movements used to achieve their goals. Just in the context of this close collaboration some possible regulatory solutions around the right to the city concept found space.

So, while the Parliament left the various drafts (about civil unions, protection by discrimination and homophobia, health issues, etc.) to remain in the drawers of politics, associations tried the strategy to press the local political level. It was a strategy that was already attempted in some other European areas.

Regional governments have first adopted a series of innovative standards in terms of protection of LGBT people's rights, such as the recognition of forms of cohabitation different from marriage, as well as specific forms of contrast to discrimination based on sexual orientation and gender identity. The regions of Tuscany, Liguria, Apulia, Emilia-Romagna, Marche, Piedmont, Umbria, Campania and Sicily issued regulations such as access to local services, contrast to discrimination, homophobia and transphobia, and the promotion of gender equality and policies concerning job placement.

The role of the homosexual social movement seems crucial in the constitution of the Italian "Rainbow Cities" (Corbisiero and Monaco 2017), places that not only have welcoming gay-friendly spaces, but that are also actively engaged at the local level to promote well-being, full inclusion and equality for LGBT citizens. On one hand these cities are engaged in the symbolic question of recognition, namely LGBT citizens' need for recognition of their identity, which was denied and disparaged by widespread prejudice. When administrations are assigned the role of guarantors of an area which respects diversity and minorities, what is called for is cultural action to combat prejudice. Along with the increasing importance of security policies on a local level, there is a growing focus on the need to guarantee the security of LGBT citizens as potential victims of homophobic and transphobic violence. 
At present some Mayors have become the main sponsors of the Italian LGBT community and the local Governments have been the center of rainbow initiatives. This liaison became a reality because it simultaneously met two needs: on one hand, the LGBT population's needs, which required resources, visibility and recognition, on the other hand, the Mayors' needs, who aimed at legitimacy and popular support (Musi 2004). ${ }^{4}$

It was a very important accomplishment: thanks to the work of the LGBT movement, a traditionally national political issue was directed to and managed by a specific local system. The innovative and proactive nature of the so-called "rainbow Mayors" resulted in the institution of a pressure instrument on Parliament.

The Mayors, with their relative autonomy, and thanks to the direct support of citizens and LGBT associations, became ambassadors of a new debate aimed at achieving the objectives of equality at a national level ${ }^{5}$. In fact, the initiatives implemented on a local level have stimulated national parliamentary discussion. Waiting for a valid legislation involving the whole territory, some Italian Municipalities have therefore found valid alternatives and effective solutions to guarantee city rights to LGBT citizens.

As a recent research on Italian cities' degree of inclusion has highlighted (Corbisiero \& Monaco 2017), "rainbow cities” in Italy are distributed throughout the territory (see Fig. 1).

The research, conducted as one of the activities of the "Osservatorio LGBT", research center of the University of Naples Federico II, classified some of the main Italian cities according to their level of openness. To give each Italian city a score, researchers built a statistical index from 0 (no inclusiveness) to 100 (maximum inclusiveness degree), starting from a set of variables, with different weights. The construction of the index provided for an accurate selection of indicators synthesised through the ACP method. More specifically, researchers considered forms, tools, performances and outcomes of services and policies implemented by local administrations for the social inclusion of LGBT people. ${ }^{6}$

\footnotetext{
${ }^{4}$ On July 7th, 1997, the Mayor of Pisa, Piero Floriani, created the municipal register of civil unions, guaranteeing the registered couples (whether same-sex or different-sex) to benefit from a series of services and policies reserved for residents in the Pisa urban territory. In the following years, many other Mayors followed his example.

${ }^{5}$ In 2005, the Democratic Party discussed the issue of same-sex unions in Parliament on a proposal by the first openly gay M.P. (Franco Grillini), supported by many Democrats' leaders of that time. During Prodi's government, the bill on Di.Co. (Rights and duties of persons permanently living together) proposed by members of the Left Democrats and the Radicals was presented. None of the Parliamentary proposals was passed because of the strong influence of the Catholic and conservative forces. In particular, these insisted on eliminating the possibility of adopting the partner's child from the Law 20 May 2016, n. 76. (Cirinnà 2017).

${ }^{6}$ See Corbisiero and Monaco 2017 for the complete research.
} 
Figure 1. Ranking of Italian rainbow cities

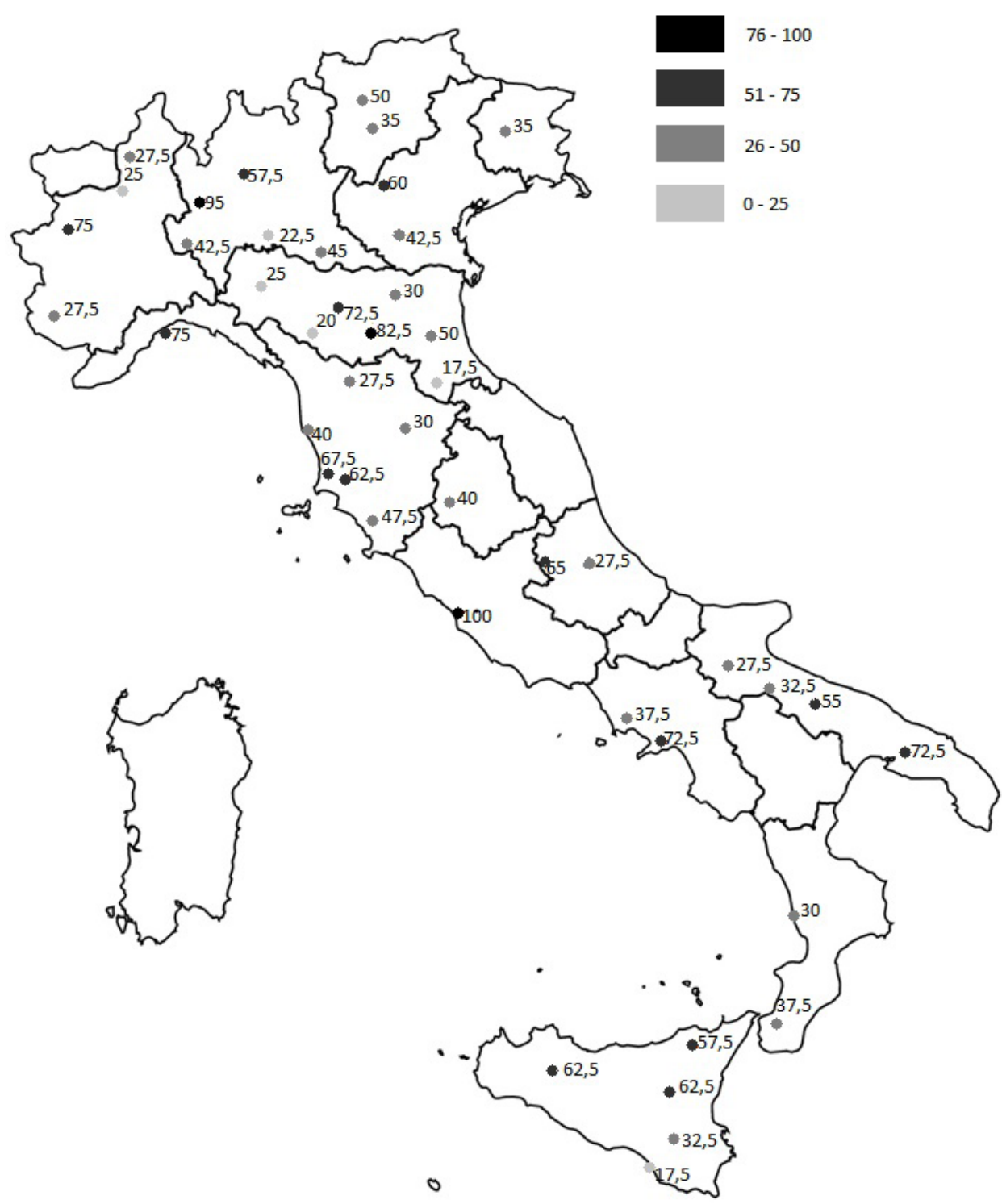

Source: Corbisiero \& Monaco 2017

The majority of Italian rainbow cities is in the Northern part of the country. The city of Turin in 2001 was the first to adopt a service for monitoring and fighting discriminations based on sexual orientation and gender identity. In 2006, the same municipal administration became promoter and leader of the RE.A.DY, a network of public administrations that choose to adopt good practices with respect to issues related to sexual orientation and gender identity (Gusmano \& Lorenzetti 2014).

In Milan, the important role of the homosexual movement, together with the role played by a social and commercial network, allowed the construction of permanent institutional and private services: the gay self-help line, the rainbow library and other consulting services. The Milan homosexual community has encouraged an ongoing 
strategic partnership with the city administration, supporting the creation of regional networks, partnerships and alliances.

In Southern Italy the main rainbow city is Naples, which lived over time a series of socio-political changes. Since the "Grand Gay Tour" times, the capital city of Campania is considered to be a capital of tolerance. In Naples, the rainbow community has gradually conquered different areas of the city: squares (such as Piazza dei Martiri formerly and Piazza Bellini later), as well as many streets. The Mayors that have managed the city from the nineties until now have all paid homosexual issues a great attention. They have sponsored events, initiatives, Gay Pride parades. In 2008, the Municipality has established the "LGBT table", where administration and associations sit and evaluate together the most appropriate strategies to be put forward.

Farther south, the city of Palermo has also distinguished itself for being one of the first to establish the municipal registry for marriages contracted out of the country. In order to protect the fundamental rights of the person, the city government has promoted the largest Gay parade in southern Europe, the "Palermo Pride" in 2013 and promotes each year the "Sicily Queer Film Fest".

Virtuous actions developed by regions and rainbow cities are designed to serve at least three purposes: from a political point of view, these actions ensure the recognition of rights, policies to fight discrimination and promote the differences; from a socio-cultural point of view, these actions are useful to give visibility and to listen to the needs of the LGBT population in order to stimulate a change in mentality and fight homophobia; from the standpoint of daily life, these actions are important to establish specific community services such as the social and healthcare assistance or legal and psychological counseling.

The Italian local governments are the most fit for understanding the problems of the LGBT population thanks to the presence of a new generation of seamless experts and specialists in various fields of equal opportunities policies.

\section{CONCLUSIONS}

At the dawn of the third millennium, the issue of homosexual people's rights has become one of the pillars of the global discourse about equality (Richardson 2005). From this point of view, during the last decade the European Union has implemented policies, guidelines and strategies to contrast any discrimination based on gender identity and sexual orientation, founding this work on the principle that all European citizens have equal value and equal dignity. Although EU law does not compel member States to recognise relationships or marriages between same-sex people, several countries in Europe have adopted same-sex marriage or civil forms similar to the legal recognition of the marriage institution (Colley 2007). Not without problems, as seen in the Italian case.

Through the right to "full citizenship" a sense of collective belonging (Parsons 1976; Durkheim 1970) and individual guarantees is acquired (Weber 1924), that qualifies people as members of a "community". As such, the citizen becomes the subject of specific rights and duties. Typically this is the granting by the State of "political and 
civil rights" (freedom of speech, thought, association, property, voters) and "social rights" (electorate, right to work, right to strike, access to subsidies, pensions, social services, health, education...). Each citizen must comply with the laws of the State and all the social conventions. However, in heteronormative societies, homosexual people are not always able to live a condition of full citizenship, having to negotiate their participation in social life on the basis of rights they are only partially granted (Lauria \& Knopp 1985; Soysal 1994).

The proactive role of the Italian homosexual social movement between the end of last century and the beginning of the present one has shown that Marshall's hypothesis of the close connection between the rights of citizenship and the enjoyment of the human rights is not always real, and for homosexual people this phenomenon is still more visible (Phelan 2001).

In Italy, the antidote to stigma, intolerance and prejudice based on heterosexism was the search for practices and principles of social inclusion, regardless of the laws in force at national level. Civil rights, those of individual freedom and equality before the law, have thus emerged thanks to the development of the urban homosexual movements.

Seen from this critical angle, it is clear that the process of freedom from homophobia and, more in general, discrimination against sexual minorities in the Italian society is accompanied by subsidiary and territorialized policies (D'Amico 2014). Under the European pressure from the center (government) to local (municipal), the principle of LGBT citizens' equality appears more and more complex, since it must take into account political, legal, and cultural identities, not always equally oriented to the implementation of practices of social justice (Plummer 2003). In this sense, the triangulation made up of "Mayors - local movements - cities" appears to be virtuous and winning, since it has acquired the traits of otherness and autonomy from the national context. Political inertia and the lack of Italian legislation isolated and forced the rainbow cities to find their own solutions in the field of citizenship rights, generating public policy devices and a number of services and good practices at the local level that are much more effective even than those of other European countries where homosexual people are safeguarded by national government initiatives.

FUNDING: This research received no external funding.

CONFLICT OF INTEREST: The authors declare no conflict of interest.

ACKNOWLEDGEMENTS: We would like to thank all the reviewers and the editor who have provided valuable feedback on this paper. A special thanks to the staff of the "Osservatorio LGBT." 


\section{REFERENCES}

Adam, Barry, Jan W. Duyvendak, and Andre Krouwel. 1999. The Global Emergence of Gay and Lesbian Politics. National Imprints of a Worldwide Movement. Philadelphia: Temple University Press.

Alderson, David. 2016. Sex, Needs and Queer Culture: From Liberation to the Post-Gay. London: Zed Books.

Armstrong, A. Elizabeth. 2002. Forging gay identities: Organizing sexuality in San Francisco, 1950-1994. Chicago: University of Chicago.

Bailey, C. Robert. 1998. Gay Politics, Urban Politics. Columbia: Columbia University Press.

Barbagli, Marzio and Asher Colombo. 2001. Omosessuali moderni. Gay e lesbiche in Italia. Bologna: il Mulino.

Bernstein, Mary. 2015. “Identity Politics.” Annual Review of Sociology 31, 1: 47-74.

Boudreau, Julie-Anne, Roger Keil, and Douglas Young. 2009. Changing Toronto: Governing urban neoliberalism. Toronto: University of Toronto Press.

Brown, Michael, and Laurry Knopp. 2003. "Queer diffusions: Environment and Planning." Society and Space 21: 409-424.

Browne, Kath. 2007. "A party with politics? (Re)making LGBTQ Pride spaces in Dublin and Brighton." Social \& Cultural Geography 8, 1: 63-87.

Browne, Kath, Lim Jason, and Brown Gavin (eds). 2007. Geographies of sexualities. London: Ashgate.

Castells, Manuel. 1983. "City and culture: The San Francisco experience" in The Castells reader on cities and social theory, edited by I. Susser. Malden: Blackwell.

Castells, Manuel, and Karen Murphy. 1982. "Cultural identity and urban structure: the spatial organization of San Francisco's gay community.” Urban policy under capitalism 20: 237-259.

Cirinnà, Monica. 2017. L'Italia che non c'era. Unioni civili: la dura battaglia per una legge storica. Rome: Fandago Libri.

Colley, Helen. 2007. Social Inclusion for Young People: Breaking Down the Barriers. Strasbourg: Council of Europe Publishing.

Corbisiero, Fabio, and Salvatore Monaco. 2017. Città arcobaleno. Una mappa della vita omosessuale nell'Italia di oggi. Rome: Donzelli Editore.

Corbisiero, Fabio. 2016. Sociologia del turismo LGBT. Milan: FrancoAngeli.

Corbisiero, Fabio. 2013. Comunità omosessuali. Le scienze sociali sulla popolazione LGBT. Milan: FrancoAngeli.

Curati, Giordana. 2013. "Il silenzio non è innocente. Esistenze lesbiche tra retrospettive e prospettive”. In Comunità omosessuali. Le scienze sociali sulla popolazione LGBT. F. Corbisiero (Ed). Milan: Franco Angeli.

D’Albergo, Ernesto, and Giulio Moini (eds.). 2007. Partecipazione, movimenti e politiche pubbliche a Roma. Rome: Aracne.

D’Amico, Giacomo. 2014. “Lgbti e diritti”. In Diritto e territorio: Il valore delle autonomie nell'ordinamento repubblicano. A. Morelli and L. Trucco (Eds.). Turin: Giappichelli.

D’Emilio, John. 1983. Sexual Politics, Sexual Communities. Chicago: Chicago University 
Press.

Doan, L. Petra. 2010. "The tyranny of gendered spaces: reflections from beyond the gender dichotomy." Gender, Place \& Culture, 17: 635-654.

Durkheim, Ėmile. 1970. La Science sociale et l'Action. Paris: PUF.

Epstein, Samuel. 1987. "Gay politics, ethnic identity: The limits of social constructionism.” Socialist Review 17, 3: 9-54.

Floyd, Kevin. 2009. The Reification of Desire: Toward a Queer Marxism. Minnesota: University of Minnesota Press.

Gargiulo, Enrico. 2008. L'inclusione esclusiva. Sociologia della cittadinanza sociale. Milan: FrancoAngeli.

Gormand-Murray Andrew, and Gordon Waitt. 2009. “Queerdfriendly neighbourhoods: interrogating social cohesion across sexual difference in two Australian neighbourhoods." Environment and Planning 41(12): 2855-2873.

Gormand-Murray, Andrew, Barbara Pini, and Lia Bryant (eds.). 2012. Sexuality, Rurality, and Geography. Lexington: Lanham MD.

Gormand-Murray, Andrew, Gordon Waitt, and Chris Gibson. 2012. "Chilling out in cosmopolitan country: urban/rural hybridity and the construction of Daylesford as a lesbian and gay rural idyll." Journal of Rural Studies 28(1): 69-79.

Grueter, C. Cyril and Tara S. Stoinski. 2016. "Homosexual Behavior in Female Mountain Gorillas: Reflection of Dominance, Affiliation, Reconciliation or Arousal?” PLoS ONE 11, 2016: 1-13.

Gusmano, Beatrice and Anna Lorenzetti (eds.). 2014. Lavoro, orientamento sessuale e identità di genere. Dalle esperienze internazionali alla progettazione di buone prassi in Italia. Rome: Armando Editore.

Harrold, Max. 1999. "Biological Exuberance: Animal Homosexuality and Natural Diversity..” The Advocate The national gay \& lesbian newsmagazine 1, 1999: 787-799.

Harvey, David. 2000. Spaces of Hope. California: University of California Press.

Harvey, David. 1989. "From managerialism to entrepreneurialism: The transformation in urban governance in late capitalism.” Geografiska Annaler 71, 1: 3-17.

Hekma, Gert. 2006. "Il mondo gay: dal 1980 a oggi”. In Vita e cultura gay. Storia universale dell'omosessualità dall'antichità a oggi. R. Aldrich (Ed.). Venice: Cicero.

Herek, M. Gregory. 2004. "Beyond «Homophobia»: Thinking about Sexual Stigma and Prejudice in the Twenty-first Century.” Sexuality Research and Social Policy 1, 2: 6-24.

Herring, Scott. 2010. Another Country: Queer Anti-Urbanism. New York: New York University Press.

Hubbard, Phil 2013. "Kissing is not a universal right: sexuality, law and the scales of citizenship." Geoforum 49: 224-232.

Humphreys, Laud. 1972. Out of the closets: The sociology of homosexual liberation. Englewood Cliffs: Prentice-Hall.

Hutte, Horst. 1978. Politics as friendship: The Origins of Classical Notions of Politics in the Theory and Practice of Friendship. Ontario: Wilfrid Laurier University Press.

ILGA. 2019. ILGA World 2018 Annual Report. Bruxelles: International Lesbian, Gay, Bisexual, Trans and Intersex Association Press. 
Jackson, Peter. 1989. Maps of meaning: An introduction to cultural geography. London: Unwin Hyman.

John, Purcell. 2003. Understanding the People and Performance Link: Unlocking the Black Box. London: CIPD Publishing.

Kramer, Jerry Lee. 1995. Bachelor farmers and spinsters: Gay and lesbian identities and communities in rural North Dakota. In Mapping desire: Geographies of Sexualities. D. Bell and G. Valentine (Eds.). London: Routledge.

Lauria, Mickey, and Lawrence Knopp. 1985. "Towards an Analysis of the Role of Gay Communities in the Urban Renaissance.” Urban Geography 6, 2: 152-64.

Lavinas Picq, Manuela \& Markus Thiel. 2015. Sexualities in World Politics: How LGBTQ claims shape International Relations. London: Routledge.

Lefebvre, Henri. 1968. Le droit à la ville. Paris: Éditions Anthropos.

Levine, Martin P. 1979. Gay Men: The Sociology of Male Homosexuality. New York: Hagerstown.

Marshall, Thomas Humphrey. 1976. Citizenship and Social Class. Cambridge: Cambridge University Press.

Meyer, H. Ilan. 2003. "Prejudice, Social Stress, and Mental Health in Lesbian, Gay, and Bisexual Populations: Conceptual Issues and Research Evidence.” Psychological Bulletin, 129, 5: 674-697.

Monaco, Salvatore. 2019. “Quartieri Gay”. In Enciclopedia Sociologica dei Luoghi. Vol. 1. G. Nuvolati (Ed.). Milan: Ledizoni.

Monaco, Salvatore, Carmine Urciuoli, \& Anna Maria Zaccaria. 2015. "Rainbow Cities: Mayors' Rules and Strategies." in Over the Rainbow City. Towards a new LGBT citizenship in Italy. F. Corbisiero. Milan: McGraw-Hill Education.

Musi, Aurelio. 2004. La stagione dei sindaci. Naples: Guida.

Muller Myrdahl, Tiffany. 2013. “Ordinary (small) Cities and LGBQ Lives.” ACME: An International Journal for Critical Geographies 12(2): 279-304.

Myslik, Wayne. 1996. "Renegotiating the social/ sexual identities of places: Gay communities as safe havens or sites of resistance?" in Body Space: Destabilising geographies of gender and sexuality, edited by N. Duncan. London: Routledge.

Parsons, Robert. 1951. Zur Theorie sozialer Systeme. Berlin: Springer.

Pezzana, Angelo. 1996. Dentro e fuori. Un'autobiografia omosessuale. Milan: Sperling \& Kupfer.

Phelan, Shane. 2001. Sexual Strangers: Gay, Lesbians, and the Dilemmas of Citizenship. New York: Temple Irvington.

Pichierri, Angelo. 2014. Sociologia dell'organizzazione. Rome: Laterza.

Pini, Andrea. 2011. Quando eravamo froci. Gli omosessuali nell'Italia di una volta. Milan: Edizioni Il Saggiatore.

Plummer, Ken. 2003. Intimate Citizenship: Private Decisions and Public Dialogues. Seattle: University of Washington Press.

Prearo, Massimo. 2015. Politiche dell'orgoglio. Sessualità, soggettività e movimenti sociali. Pisa: ETS.

Reckless, C. Walter. 1926. "The distribution of commercialized vice in the city: A sociological analysis.” Publications of the American Sociological Society 20: 164-176. 
Richardson, Diane. 2005. "Claiming Citizenship? Sexuality, Citizenship, and Lesbian Feminist Theory." in Thinking Straight: The Power, the Promise, and the Paradox of Heterosexuality, edited by C. Ingraham. New York-London: Routledge.

Rinaldi, Cirus. 2012. Alterazioni: introduzione alle sociologie delle omosessualità. Milan: Mimesis.

Romeo, Graziella. 2011. La cittadinanza sociale nell'era del cosmopolitismo: uno studio comparato. Milan: Wolters Kluwer.

Rossi Barilli, Gianni. 1999. Il movimento gay in Italia. Milan: Feltrinelli.

Sanna, Gabriella and Valeria Bersacchi (eds.). 2000. Roma multietnica. Guida alla città invisibile. Rome: Villaggio Editoriale.

Soysal, Yasemin. 1994. Limits of Citizenship. Chicago: University of Chicago Press.

Symanski, Richard. 1974. "Prostitution in Nevada." Annals of the Association of American Geographers 64, 3: 357-377.

Tongson, Karen. 2010. Relocations: Queer Suburban Imaginaries (Sexual Cultures). New York: New York University Press.

Weber, Max. 1924. Gesammelte Aufsätze zur Soziologie und Sozialpolitik. Mohr: Tübingen.

Weinberg, Thomas S. 1983. Gay Men, Gay Selves: The Social Construction of Homosexual Identities. Philadelphia: Philadelphia University Press.

Weinberg, Martin S., and Colin J. Williams. 1974. Male homosexuals: their problems and adaptations. Oxford: Oxford University Press.

Weston, Kath. 1998. Long Slow Burn: Sexuality and Social Science. London: Routledge.

\section{BIOGRAPHICAL NOTE}

Fabio Corbisiero is Associate Professor at the Department of Social Sciences of the University of Naples Federico II. He is scientific director of "Osservatorio LGBT" and "OUT Osservatorio Universitario sul Turismo" at the same University. His research mainly concerns the field of urban sociology, with a specific reference at tourism and urban contexts in the dimension of social inequality and minorities (LGBT people, migrants, people with disabilities).

Salvatore Monaco is Postdoctoral Researcher in Sociology at the Faculty of Education, Free University of Bozen. He is a researcher of "Osservatorio LGBT" and "OUT Osservatorio Universitario sul Turismo" of University of Naples Federico II. His research interests include tourism, technologies and territories with particular focus on identities, genders, sexual orientations and generations.

OPEN ACCESS: This article is distributed under the terms of the Creative Commons Attribution Non-commercial License (CC BY-NC 4.0) which permits any non-commercial use, and reproduction in any medium, provided the original author(s) and source are credited.

ARTICLE HISTORY: Received 2020-01-16 / Accepted 2020-05-21 
